\title{
Local government as institutional entrepreneur: public-private collaborative partnerships in fostering regional entrepreneurship
}

Article

Accepted Version

Xing, Y., Liu, Y. and Cooper, C. L. (2018) Local government as institutional entrepreneur: public-private collaborative partnerships in fostering regional entrepreneurship. British Journal of Management, 29 (4). pp. 670-690. ISSN 1467-8551 doi: https://doi.org/10.1111/1467-8551.12282 Available at https://centaur.reading.ac.uk/81586/

It is advisable to refer to the publisher's version if you intend to cite from the work. See Guidance on citing.

To link to this article DOI: http://dx.doi.org/10.1111/1467-8551.12282

Publisher: Wiley

All outputs in CentAUR are protected by Intellectual Property Rights law, including copyright law. Copyright and IPR is retained by the creators or other copyright holders. Terms and conditions for use of this material are defined in the End User Agreement. 


\section{CentAUR}

Central Archive at the University of Reading

Reading's research outputs online 


\title{
Local Government as Institutional Entrepreneur: Public-Private \\ Collaborative Partnerships in Fostering Regional Entrepreneurship
}

\author{
Yijun Xing \\ School of Economics and Management \\ Beijing Jiao Tong University \\ 100044 Beijing, China \\ Email: dr.yijunxing@gmail.com
}

\author{
Yipeng Liu* \\ Newcastle University Business School \\ Newcastle University \\ NE1 4SE Newcastle upon Tyne United Kingdom \\ Tel: +44 (0) 1912081729 \\ Email: Yipeng.Liu@Newcastle.ac.uk
}

\author{
Sir Cary L. Cooper \\ 50th Anniversary Professor of Organizational Psychology and Health \\ Manchester Business School, \\ University of Manchester \\ Booth Street West, Manchester M15 6PB, United Kingdom \\ Email: cary.cooper@mbs.ac.uk
}

\section{Acknowlegement:}

This research has been supported by The British Academy under the grant number PM160173 and The Leverhulme Trust under the grant number RF-2017-235\7.

*) corresponding author 


\begin{abstract}
Due to the intertwined nature of private and public interests, local governments tend to use collaborative partnerships involving entrepreneurs to promote regional entrepreneurship. However, there is still a gap in the theory with regard to the mechanisms underpinning these collaborative partnerships. Drawing on institutional entrepreneurship literature, we identify the enabling conditions and articulate the role played by local government as an institutional entrepreneur in fostering regional entrepreneurship through entrepreneurial public-private collaborative partnerships. This paper explicates two distinct mechanisms - the establishment of new institutional arrangements by the institutional entrepreneur, and the advocation of diffusion by other actors - that underpin entrepreneurial public-private collaborative partnerships. Importantly, we underscore the crucial role played by returnee entrepreneurs who interact collaboratively with the institutional entrepreneur in affecting institutional change and fostering regional entrepreneurship. We conduct in-depth qualitative interviews with local government officials, entrepreneurs, and high-tech park managers, in conjunction with performing content analysis of policy documents in a peripheral region of China-areas that have been largely neglected in scholarly research. This paper concludes with some theoretical and policy implications for public management and entrepreneurship.
\end{abstract}

Keywords: China, local government, collaborative partnerships, institutional entrepreneurship, micro-foundation, returnee entrepreneurs 


\section{Introduction}

Entrepreneurship has received considerable worldwide attention from management academics, the business community, and policymakers. The promotion of entrepreneurship can help address the societal and economic challenges facing the global economy, especially when the social value of entrepreneurship is considered (Zahra \& Wright, 2016). Increasingly, due to the intertwined nature of the public and private interests, public organizations also recognize the value of entrepreneurship (Klein, Mahoney, McGahan \& Pitelis, 2013). In order to exploit the value of entrepreneurship, governmental and governmental-related organizations are keen to promote entrepreneurship for regional development and prosperity (Isenberg, 2010). Entrepreneurship can be viewed as a collective endeavour that involves multiple actors interacting dynamically (Lippmann \& Aldrich, 2016). The vibrant literature stream on returnee entrepreneurship also demonstrates the collaborative nature, when scientists and engineers trained in the United States or other OECD countries return to their home countries to start up a new venture (Wright, Liu, Buck \& Filatotchev, 2008; Liu \& Almor, 2016; Liu, 2017a).

Hence, a nuanced understanding of the interactive relationship between government and entrepreneurs is salient to better leverage the power of entrepreneurship, especially in emerging economies in which the allocation and utilization of critical resources are often under government control (Armanios, Eesley, Li \& Eisenhardt, 2017; Smallbone \& Welter, 2012). We view collaborative partnerships involving public and private business actors as an important organizational form (Liu, Sarala, Xing \& Cooper, 2017) that can shed some light on how governments interact with entrepreneurs. Collaborative partnerships emerged as a new organizational form of public management, especially those emphasizing the interdependences between private and public interests (Mahoney, McGahan \& Pitelis, 2009). Although publicprivate collaborative partnerships have received increasing scholarly attention, the existing research failed to illuminate the fine-grained and nuanced mechanisms in various forms of 
public-private and cross-sector collaboration from a micro-foundational perspective (Quelin, Kivleniece \& Lazzarini, 2017).

Institutional theory has been identified as a promising theoretical perspective for the study of public management (Ashworth, Ferlie, Hammerschmid, Moon \& Reay, 2013). Institutional entrepreneurship explains the institutional change process with existing studies having largely focussed on advanced Western economies (Battilana, Leca, \& Boxenbaum, 2009). Due to context-specific factors, institutional change in regions other than the Western world does not necessarily follow the same path of de-institutionalization and re-institutionalization (Greenwood \& Suddaby, 2006). In non-Western contexts, only a few studies examined the role played by the state as institutional entrepreneur (Child, Lu \& Tsai, 2007; Jain \& Sharma, 2013; Nasra \& Dacin, 2010). A close examination of these studies reveals that emerging economies may challenge theories developed to explain phenomena occurring in relatively stable and mature economies (Bruton, Ahlstrom \& Obloj, 2008; Xu \& Meyer, 2013). In particular, emerging economies provide a natural experiment to study the boundary conditions of prevalent theories, and thus contribute to the advancement of theoretical development (George, 2014; Johns, 2017).

We aim to uncover the underlying mechanisms of collaborative partnerships involving local governments and private entrepreneurs (hereafter referred to as 'entrepreneurial public-private collaborative partnerships') during the process of institutional change in China. Up to now, little research has been conducted on the mechanisms by which local governments engage in entrepreneurial public-private collaborative partnerships to foster entrepreneurship. The same goes for why and how the actions that constitute such collaborative partnerships vary with different actors. To fill this theoretical gap, we conducted a qualitative study that examines the role of local government in fostering regional entrepreneurship in China, and explores the mechanisms underpinning the actors' various actions. Thus, our research questions include: 
How can governments foster regional entrepreneurship through entrepreneurial public-private collaborative partnerships? What are the mechanisms by which local governments may interact with private entrepreneurs to foster regional entrepreneurship in emerging economies?

This paper presents a qualitative study of the institutional change that produced new practices in fostering regional entrepreneurship in a peripheral region of China. We chose to take a qualitative approach to this study for two reasons. First, the focal phenomenon (institutional change leading to the fostering of regional entrepreneurship in China) has not been theoretically well understood. While the thinking, pertaining to entrepreneurial policy attracting returnees to China from abroad (Wang \& Liu, 2016) and to the role of returnee entrepreneurs (H. Li, Y. Zhang, Y. Li, Zhou \& W. Zhang, 2012; Liu, 2017a), has developed rapidly, the sudden and relatively recent appearance of regional- and national-level policy programmes challenges the traditional understandings of the role played by governments and entrepreneurs in China (Nee \& Opper, 2012). Second, we aim to develop a contextualized and nuanced understanding of the constituent activities and contested nature of institutional change by examining the mechanisms by which local governments act as institutional entrepreneurs in initiating entrepreneurial public-private collaborative partnerships, whereas private entrepreneurs collaboratively interact with the institutional entrepreneur.

This study contributes in several ways to our understanding of such collaborative partnerships in the context of local governments fostering regional entrepreneurship. First, by examining them as a multifaceted phenomenon, we provide insights into the different roles played by various actors and into their interactions with local governments in fostering regional entrepreneurship. Second, our study identifies two mechanisms - namely, the establishment of new institutional arrangements and the advocation of diffusion - underpinning entrepreneurial public-private collaborative partnership and the likely interaction between local governments and other actors. In particular, our findings explain the actions of local governments as 
institutional entrepreneurs and the mechanisms by which they undertake entrepreneurial publicprivate collaborative partnerships in fostering regional entrepreneurship. The article begins by reviewing the literature on the role of governments and collaborative partnerships, returnee entrepreneurship, and institutional change. We then present the research context and design of the study and discuss our empirical findings. The article concludes by outlining its theoretical and policy implications.

\section{Theoretical background}

\section{The role of governments and collaborative partnerships in fostering entrepreneurship}

Governments are important institutional actors influencing entrepreneurial activities (Minniti, 2008; Zahra \& Wright, 2011). Governments can design and nurture innovative solutions that foster the development of regional and local economies. Although the interrelationship between governments and entrepreneurship is complex, the former can promote the latter by contributing to the development of institutional arrangements aimed at boosting entrepreneurial activities (Spencer, Murtha \& Lenway, 2005). For example, policies involving tax breaks and financial subsidies may energize emerging new sectors (Ribeiro-Soriano \& Galindo-Martín, 2012). One study found that entrepreneurship policies undertaken by the UK Labour governments between 1997 and 2010 helped improve regional competitiveness by addressing the economic and social problems constraining new business formation (Huggins \& Williams, 2011). Furthermore, local governments play a leading role in sustainable development by striking collaborative partnerships between communities, industries, and other government entities (Liou, 2009). However, there is the urgent need to fill the theoretical gap and uncover the relevant inter-level links and mechanisms connecting institutions, entrepreneurship, and economic growth (Bjørnskov \& Foss, 2016). 
Furthermore, the new 'Statism' in the age of globalization presents fresh challenges and opportunities for governments and entrepreneurship (Wood \& Wright, 2015). In particular, governments in emerging economies control the allocation and utilization of critical public resources (Armanios et al., 2017), thus exerting a strong influence on regional development and entrepreneurship, (Smallbone \& Welter, 2012) and playing a particularly important role in the development of entrepreneurial activities (Bruton, Filatotchev, Si \& Wright, 2013). Examples of this important governmental role in stimulating entrepreneurial activities include the vibrant international entrepreneurship activities in Dubai (Nasra \& Dacin, 2010), the emergence and development of India's national telecommunications industry (Jain \& Sharma, 2013), and the rapid development of the solar photovoltaic industry in China (Liu, 2017a).

The public entrepreneurship literature suggests that, due to the intertwined nature of private and public interests (Mahoney et al., 2009), public organizations can leverage entrepreneurship to address societal and economic challenges and, at the same time, should adopt a strategic perspective in doing so (Klein et al., 2013). Hence, collaborative partnerships between governments and other actors may offer a pathway to tackle the societal challenges facing the contemporary world economy. As an alternative approach to market competition, collaborative partnerships emphasise the engagement of and collaboration among multiple actors in delivering goods and services with mutual benefits for multiple stakeholders (Hartley, Sørensen \& Torfing, 2013). Previous research suggested that public entrepreneurship reflects an evolutionary process by which an initially strong government takes on the role of a weak one under the pressure of the systemic participation of other actors (Bernier \& Hafsi, 2007). For instance, the emergence within regions of entrepreneurially-oriented cohesive groups with a collaborative approach contributes to those regions' entrepreneurial activities (Lippmann \& Aldrich, 2016). 
However, the extant research did not explicate the mechanisms through which the dynamic and interdependent interactions between governments and other actors may unfold in collaborative partnerships. The most recent body of knowledge on private-public collaborations echoes the existence of such a theoretical gap and urges future research to explore the micro-foundations of the diverse forms of public-private and cross-sector collaborations (Quelin et al., 2017). Therefore, we aim at uncovering how governments can foster regional entrepreneurship through entrepreneurial public-private collaborative partnerships.

\section{Returnee entrepreneurship and institutional change}

The vibrant research stream on returnee entrepreneurship has gained increasing attention from academic scholars. "Returnee entrepreneurs are the scientists and engineers trained in the United States or in other OECD countries, who return to their home countries to start up a new venture" (Wright, et al, 2008: 132). From a comparative perspective between returnees and local entrepreneurs, the existing research offered interesting findings on entrepreneurial behaviours and organizational performance. For instance, due to cultural influences, returnees may deal with uncertainty differently from local entrepreneurs (Liu \& Almor, 2016). Returnees and local entrepreneurs can contribute to engendering different performance profiles for companies, as returnees may facilitate knowledge transfer and initiate spillover effects on local innovation in emerging economies (Filatotchev, Liu, Lu, \& Wright, 2011). However, returnees may not possess relevant knowledge of the local context; thus, science parks, as institutional intermediaries, can compensate for a lack of context relevance by legitimizing returnees to obtain public resources (Armanios et al., 2017).

At the industry level, by leveraging their knowledge about global market and international networks (Liu, Lu, Filatotchev, Buck, \& Wright, 2010), returnees can accelerate the 
developmental process of high-tech industries in emerging economies (Kenney, Breznitz, \& Murphree, 2013). A more recent study revealed that returnees act as knowledge brokers in conducting the transfer of knowledge from abroad to their home countries (Wang, 2015). Another study demonstrated that returnee entrepreneurs in emerging economies can contribute to build the entrepreneurship ecosystem from a multi-level perspective (Liu, 2017b). However, the extant research failed to articulate the role played by returnee entrepreneurs in the context of collaborative partnerships, and the mechanisms by which returnee entrepreneurs may interact with local governments towards institutional change in emerging economies.

The vibrant development of institutional theory is reflected in management and organizational studies (Greenwood, Hinings \& Whetten, 2014) associated with distinctive pluralism and salient notions - such as institutional complexity, institutional logics, and institutional entrepreneurship (Zietsma, Groenewegen, Logue, \& Hinings, 2017). This pluralism is conducive to explaining the complexity and dynamics of institutions and institutional change (Lounsbury \& Beckman, 2015). Institutional entrepreneurship refers to the "activities of actors who have an interest in particular institutional arrangements and who leverage resources to create new institutions or to transform existing ones" (Hardy \& Maguire, 2008). The involvement of multiple actors in institutional entrepreneurship has also been noted (Lounsbury \& Crumley, 2007; Wijen \& Ansari, 2007), and collective and collaborative action has been identified as a key activity undertaken by institutional entrepreneurs (David, Sine \& Haveman, 2013). For instance, one study of product innovation dealing with the English County Cricket Association's Knockout Cup described how an institutional entrepreneur had adopted a collective approach to acquire and deploy resources (Wright \& Zammuto, 2013).

In emerging economies, building new institutions can be a salient phenomenon, as the legal institutions are relatively weak, and both the professional and commercial norms are in the making (Jennings, Greenwood, Lounsbury \& Suddaby, 2013). For example, institutional 
entrepreneurship is advanced in a relatively experimental manner and the strategies adopted are more minimalist, incremental, and delicate than the existing literature on institutional change suggests (Mair \& Marti, 2009). In building environmental protection systems in China, the special characteristics of institutional entrepreneurship have strongly resonated with the important functions assumed by the state (Child et al., 2007). Furthermore, institutional changes that reduce barriers to growth can significantly influence the propensity of individuals to found businesses in China (Eesley, 2016). Building upon micro-foundational thinking (Felin, Foss \& Ployhart, 2015) and on the recent call to explore the micro-foundations of institutional impacts on the macro consequences of institutional arrangements (Gehman, Lounsbury \& Greenwood, 2016), our study aims to fill the theoretical gap in the influence of entrepreneurial public-private collaborative partnerships on institutional change.

\section{Research method}

For this study, we adopted a social constructionist view and embraced a discovery-driven field research method (Locke, 2011). The exploratory research questions and the contextual features associated with emerging economies determined our choice of a qualitative research method aimed at gaining a nuanced understanding of local government and collaborative partnership (Edmondson \& McManus, 2007). We used a multi-method approach (Vaara \& Monin, 2010) consisting of historical case studies and event sequencing, in-depth interviews, and content analysis of government and association reports. We sought to reveal the underlying mechanisms and social dynamics of collaborative partnership by using several complementary sources of data and methods of analysis. This approach led us to collect different types of qualitative data from diverse sources. 


\section{Research context}

As for the research setting, we chose Wuxi, a second-tier city, which promotes high-tech entrepreneurship, for three reasons. First, in 2006 the Wuxi local government established the 530 Plan, a local government policy initiative designed to attract overseas Chinese technology entrepreneurs. Second, Wuxi nurtured the largest Chinese solar photovoltaic company, Suntech Power, which was listed on the New York Stock Exchange (NYSE) in 2005, and by 2012 Suntech Power had become one of the world's largest solar energy companies. Third, Wuxi is a typical peripheral region, which differs greatly from first-tier Chinese metropolises like Beijing and Shanghai. Scholars have paid relatively little attention to peripheral regions, especially in the context of emerging economies.

Furthermore, our choice of empirical context and its potentially significant contribution to the public management and entrepreneurship literature, with important policy implications, was motivated by two additional reasons relating to industry choice and country choice. First, in the past decade, public management studies have tended to be dominated by certain sectors, especially healthcare. For example, earlier research investigated organizational change (Battilana \& Casciaro, 2012; Reay, Golden-Biddle \& Germann, 2006) in the healthcare sector. Studying a wide spectrum of public organizations is important, as it can generate new insights on this matter; thus, the lack of attention to aspects of local government results in ignoring the core actor in the public management domain, even though local government is an important topic in both public management and general management studies (Greenwood \& Hinings, 1993; Hinings \& Greenwood, 1989). Our examination of local government can generate revealing insights that contribute to the debate on public management in the current turbulent business and economic environment facing local governments.

As for country choice, we argue that novel contexts, such as emerging economies, can have important implications for the theoretical advancement and empirical refinement of public 
management studies. Last, but not least, studies conducted on China tend to focus on large metropolitan areas such as Beijing, Shanghai, and Guangzhou and fail to provide fine-grained and nuanced accounts of local government in second-tier Chinese cities. As a polity, China is relatively decentralized with respect to its organization $(\mathrm{Xu}, 2011)$; regional variations thus illustrate the dynamics and changes in regulatory frameworks and institutions, as exemplified by the emergence of the Chinese private entrepreneurial sector (Nee \& Opper, 2012). We argue that our empirical setting is appropriate for the investigation of the mechanisms by which local government undertakes entrepreneurial public-private collaborative partnerships in fostering regional entrepreneurship.

\section{Content analysis and in-depth interviews}

We combined content analysis with in-depth interviews. Doing just content analysis may not have uncovered valuable insights and the underlying logic employed by institutional entrepreneurs. In-depth interviews with key actors can provide further insights into the process of institutional change, which becomes a source of rich information that goes beyond what can be extracted from the documentary data (Thornton \& Ocasio, 1999). Storytelling interviews offer another possibility for uncovering hidden information (Zilber, 2006). There has been growing interest among scholars and practitioners in the applicability of storytelling as a research method in organization and management studies (Liu, Xing \& Starik, 2012; Rosile, Boje, Carlon, Downs \& Saylors, 2013). The combined use of intensive in-depth interviews and archival records can benefit scholars in the study of institutional change (Dacin, Goodstein \& Scott, 2002).

\section{Data collection}


The primary data were collected mainly through the authors' contacts and professional networks. The intensive data collection carried out over a 29-month period involved in-depth interviews, observation of meetings and events, high-tech park tours, and extensive documentary analysis. Thirty-two in-depth interviews were conducted with informants, including government officials and high-tech park managers working closely with 530 companies, successful pioneer returnee entrepreneurs before the launch of the 530 Plan, as well as those entrepreneurs who participated in the 530 Plan and those who did not. The interviewees were selected by including the key actors who contribute to fostering regional entrepreneurship. The selection of samples purposefully focussed on both government officials and entrepreneurs, while the interaction and collaborative activities between different actors were given special attention. The analytical focus of the study is the collaborative partnership among different actors, especially the entrepreneurial public-private collaborative partnerships. Table 1 presents an overview of the primary data, showing the distribution of interviewees between the different groups. This balanced approach to data collection enabled us to obtain multiple and complementary perspectives on the role of local government in fostering regional entrepreneurship.

Insert Table 1 About Here

We adopted the theoretical sampling method, stopping when further interviews ceased to generate additional significant information. The interviews lasted between 40 and 120 minutes and were tape-recorded and transcribed. We analysed the interviews using the NVivo 9 software tool. For triangulation purposes, we obtained secondary data from archives, such as newspapers, media articles from the national and international press, websites, governmental brochures and promotional materials, and internal reports of governmental foreign trade and investment 
agencies. Table 2 provides an overview of the policy documents the content of which has been analysed in this study.

Insert Table 2 About Here

In analysing our data, we followed the grounded theory approach (Gioia, Corley \& Hamilton, 2013). We elucidate the data analysis process by displaying data structure in Figure 1, and showing first-order coding, second-order coding, and aggregated theoretical dimensions with selective empirical evidence in Table 3 to illuminate the underlying mechanisms for institutional entrepreneurship and collaborative partnerships.

INSERT Figure 1 ABOUT HERE

INSERT Table 3 ABOUT HERE

\section{Findings}

\section{Local government as an institutional entrepreneur and the related enabling conditions}

Our empirical analysis reveals the significant role played by local government in fostering regional entrepreneurship. Three distinctive factors enable local government to take entrepreneurial action as an institutional entrepreneur: (a) the functional and political pressures faced by local government; (b) the entrepreneurial opportunity presented for the local government; and (c) the ability of local government to mobilize resources.

From the public management perspective, our research indicates that local government faces functional and political pressures stemming mainly from intensive regional competition. In the Chinese governmental system, local and regional political authorities are appointed by the central government but are free to devise their own regional and local economic development 
strategies $(\mathrm{Xu}, 2011)$. Differences in local conditions create an intense and varied competition between different local governments. The head of the department in charge of local economic development stated:

"Wuxi is a peripheral region, not like Shanghai that receives worldwide attention. Shanghai is the primary location chosen for Fortune 500 company headquarters in China, and the priority of the Shanghai government is to attract Fortune 500 companies. Although the local Wuxi government has worked hard to attract foreign direct investment (FDI), Wuxi lags far behind Shanghai in luring Fortune 500 companies."

The competition between different regions places functional and political pressure on the Chinese local governments to seek engines for local economic growth. These pressures were articulated by the Chief of Staff of Labour Resources in Wuxi:

“Wuxi's local economy was supported mainly by the manufacturing and textile industries in the early 2000s. That industrial structure polluted the local environment and was unsustainable in the long run for purposes of regional economic growth. Therefore, the local government faces enormous pressure to upgrade its industrial structure. In 2011, Wuxi's key economic engine and contributor is renewable industry, namely, the solar sector. This local structural change in the industry is due to the entrepreneurial behaviour of the local Wuxi government, which supports solar companies."

From the perspective of entrepreneurship, our analysis showed that the local Wuxi government discovered an entrepreneurial opportunity and successfully mobilized its resources. James, the director of the Wuxi 530 Entrepreneur Service Centre, explained:

"Armed with know-how and industry experience in the solar energy technology, Dr. Shi wanted to found his own solar venture in China in the early 2000s. He visited several 
places in China before meeting Mr. Li, former Director of Foreign Economics and Trade in Wuxi. Dr. Shi asked mainly for financial support, as solar panel manufacturing is capital intensive. Dr. Shi was turned down by all other regions except Wuxi. Promoted strongly by Mr. Li, the solar industry has the potential to upgrade local industrial structure. Therefore, the Wuxi local government decided to invest in this entrepreneurial opportunity."

This entrepreneurial behaviour was associated with risks and uncertainties because the solar energy sector had not proved its market potential. Moreover, given that the fundamental logic of the local government was FDI-oriented, this departure from its original plan demonstrates exceptional entrepreneurial spirit. The local Wuxi government mobilized the necessary resources to take advantage of the entrepreneurial opportunity that presented itself by promoting the manufacture of solar panels. The chairman of WXOCICC explains:

"After performing due diligence on Dr. Shi in Australia, the local Wuxi government decided to make the investment. However, there was no template available on how to invest. Mr. Li assembled six million USD from State Owned Enterprises (SOE), e.g., Little Swan, to invest in Suntech. It was not a formal investment but rather an informal one led by Mr. Li.",

Mobilizing resources played a crucial role in taking advantage of that solar panel manufacturing entrepreneurial opportunity. Although the local government did not have an official procedure, Mr. Li, on behalf of the local government, exploited this particular entrepreneurial opportunity. Institutional conditions enabled the local government to conduct a trial-and-error experiment and test an alternative approach to spur regional economic growth.

To advance the understanding of the role of the state in promoting international entrepreneurship and institutional change in emerging economies (Jain \& Sharma, 2013), our 
analysis revealed that local government is the institutional entrepreneur in China and identified three factors enabling it to effectively function as such as shown in Table 4.

Insert Table 4 About Here

\section{Collaborative partnership in fostering regional entrepreneurship}

Our analysis identified temporal changes in the role played by local government with two distinctive mechanisms: the establishment of institutional arrangements by local government and the advocation of diffusion by private entrepreneurs. We traced the important events concerning Suntech Power from 2001 to 2010, using them to provide a narrative account of the entrepreneurial actions taken by the institutional entrepreneur-i.e., the local Wuxi government. In so doing, we aimed to illuminate the temporal dimension in institutional change and the shift from government-led new institutional arrangement initiatives to other actors-participated diffusion practices.

\section{The establishment of new institutional arrangements}

Our analysis indicates two practices underpinning the mechanism of the establishment of new institutional arrangements by the institutional entrepreneur - namely, modifying and separating from existing institutions. The institutional entrepreneur can mobilize and utilize resources to pilot policy initiatives with new institutional arrangements. At this phase, entrepreneurial public-private collaborative partnerships are dominated by the institutional entrepreneur.

\section{Modifying}

Modifying means changing the routines and rules that have been taken for granted in order to respond to institutional pressures and processes (Oliver, 1991). In the case of Wuxi, the local and regional governmental authorities were eager to seek new engines for regional economic development that could not be sustained by older industries. This situation created the opening needed by local government to modify the existing patterns of local economic development. As 
noted above, the local government was aware of existing functional and political pressures. The entrepreneurial opportunity brought on by the overseas entrepreneur prompted the local government to modify its existing routines and rules and explore a new approach. Furthermore, the regional economic policy was consistent with a selection strategy intended to match local industrial profiles with economic development targets. Traditional industrial jobs were filled mainly by relatively low-skilled labour, whereas the high-tech sectors, such as renewable energy, needed well-educated and highly skilled workers, and the overseas entrepreneurs who considered moving to Wuxi typically had advanced educational credentials. A director of the 530 service department explained the consequences of the presence of overseas entrepreneurs in Wuxi:

"The arrival of talent upgrades the composition of the citizenry. In the past, Wuxi lacked culture. For example, there is only one university here. Now we attract many highlyeducated entrepreneurs. Large numbers of them have PhD degrees from abroad."

The intention to modify the local economic structure and to improve Wuxi's socio-cultural atmosphere was conducive to the local government's establishment of new institutional arrangements for the purpose of promoting regional entrepreneurship and economic development.

\section{Separating from existing institutions}

Another practice that underpins the establishment of new institutional arrangements is separating from existing institutions. Initial success plays a critical role in the institutional entrepreneur's ability to establish the legitimacy of its support for a pilot initiative. Suntech's success enabled the local government to carry out institutional changes and establish new institutional arrangements, explicitly Wuxi's 530 Plan.

Because of European renewable energy laws, such as Germany’s Feed-in Tariff, Suntech had experienced rapid growth and development up to 2004, seizing market opportunities in Europe 
and North America (Liu, 2017a). Its rapid growth and success led to Suntech's next development phase, in which the Initial Public Offering (IPO) represented a critical juncture.

The chairman of WXOCICC explains:

"The local Wuxi government was determined to let Dr. Shi become rich through an NYSE IPO. Local government strongly supported technology entrepreneurs and wanted to create a role model for follow-up entrepreneurs. This statement sent a strong signal that the Wuxi government respects the achievements of high-tech entrepreneurs and is willing to protect their benefits."

The success of the Suntech IPO pioneered a new regional economic development model in fostering regional entrepreneurship. Internal disputes within the local government-regarding whether it should remain involved in this process or exit before the Suntech IPO-resulted in the resignation of Mr. Li. Nevertheless, the local government, as an institutional entrepreneur, took deliberate action to build a model for future technology-based entrepreneurs in Wuxi. The Suntech case came to be regarded as the prototype for the Wuxi 530 Plan (Liu, 2011).

The 530 Plan clearly illustrates the deliberative efforts of the institutional entrepreneur to respond to requests from overseas technology-based entrepreneurs. In April 2006, after the successful Suntech IPO, the Wuxi government established a special policy instrument - the 530 Plan-exclusively targeting advanced Chinese overseas technology-based entrepreneurs. The Wuxi government had put in place a favourable policy to assist overseas Chinese entrepreneurs in setting up their technology-based ventures in the city.

A director at a Wuxi Economic Development Zone notes:

“There was no 530 Plan in 2001. Suntech was a successful case. Later on, Wuxi saw the benefits it can derive from overseas technological talent in upgrading the local 
economic structure. Therefore, the Wuxi government decided to set up the 530 Plan to attract overseas entrepreneurs."

The creation of the 530 Plan was an instance of a local government successfully establishing a new institutional arrangement. In the initial stages of institutional change, the institutional entrepreneur has the power and authority to create formal institutions. The 530 Plan was established within the existing institutional environment as a separate entity. Overseas entrepreneurs could directly exploit this policy to receive favourable conditions. Literally, '530' referred to the fact that, that over a period of ' 5 ' years, the Wuxi local government intended to create ' 30 ' successful technology-based enterprises similar to Suntech. A branded entrepreneurial policy, called '3 times 100' included: (a) a start-up capital of one million RMB (100 Wan RMB, in Chinese); (b) 100 square meters of workplace; and (c) 100 square meters of accommodation free of charge for three years. These favourable conditions helped start-up entrepreneurs reduce their risk exposure when establishing new ventures. Local government, as an institutional entrepreneur, must take the lead in legitimizing any new government policies aimed at attracting overseas talent. Thus, we posit the following:

Pla: Initial success motivates institutional entrepreneurs to establish separate entities outside of the general institutional environment to protect initial institutional change

P1b: Initial success spreads the legitimacy needed for other actors to support institutional change

\section{The advocation of diffusion}


Although institutional entrepreneurs can establish new institutional arrangements, local governments are unable to carry out everything on their own. Therefore, institutional entrepreneurs collaborate with other actors by mobilizing and leveraging resources to maintain policy momentum by means of new institutional initiatives. Together with the creation of a high-tech, entrepreneur-friendly environment, our analysis revealed two practices involved in maintaining the institutions underpinning entrepreneurial public-private collaborative partnerships: offering ancillary services and complementing the role of the government.

\section{Offering ancillary services}

One important function of other actors in the advocation of diffusion is to offer ancillary services. In seeking to foster regional entrepreneurship, Wuxi's local government began collaboratively developing new service offerings for overseas entrepreneurs to maintain the momentum of the initial institutional change. From 2006 to 2010, overseas entrepreneurs were provided with ancillary services to help them surmount start-up issues. In particular, the local government created the Wuxi 530 service office to streamline the setting up of activities for overseas entrepreneurs; this involved help with registration, legal and tax consultation, as well as with arranging schools and healthcare for family members. An important association that worked collaboratively with the local government was the WXOCICC (Wuxi Overseas Chinese Investment Chamber of Commerce), which mainly consists of private overseas entrepreneurs. The association helped establish connections between newly arrived overseas entrepreneurs and local Chinese business partners.

The Chairman of the WXOCICC explains the value it added to 530 companies:

"These graduates with overseas PhDs are good at $R \& D$. A 1-2 person team is easy to manage. But, later on, marketing, products, sales, and management are challenges for them. Industrialization and the IPO raise various issues for overseas entrepreneurs. The 
Wuxi government provides complementary services. We offer services to '530' entrepreneurs, too. More importantly, we have real-life experience because we have been entrepreneurs."

The above narrative indicates that the WXOCICC offered ancillary services to advocate the diffusion of activities. Our analysis reveals that local businesses and entrepreneurs provided ancillary services to support returnee entrepreneurs growing their businesses, including tax accountants, law companies, marketing and sales agents, and recruiting agents. These ancillary services provided by other actors not only helped returnee entrepreneurs to overcome obstacles, but also supported the policy initiatives piloted by institutional entrepreneurs. In so doing, it generated momentum and lent its support to advocate the diffusion of regional entrepreneurial policies at the local community level.

\section{Complementing the role of the government}

The additional important function taken on by private entrepreneurs in advocating diffusion is to complement the role of the governments. Governments should discharge the function of creating and maintaining a market environment that enables other actors and companies to operate and compete (Spencer et al., 2005). However, the governments of emerging economies tend to expand their function into business activities, as borne out by the prevalence of government-run venture capital funds (White, Gao \& Zhang, 2005). When a government lacks special expertise in running commercial and business activities, local entrepreneurs and local business can collaborate with it. A professional service company owner explained the change the local government underwent while interacting with them:

"I feel that the local government now is very open. They actively outsource specialized tasks to professionals. I think that running a company is not the local government's strength. The local government trusts the professional service companies, including VCs. Looking from the perspective of the high-tech park operation, we helped carry out 
several functions on behalf of the local government. Actually, several tasks that in the past belonged to the government are now given to us."

The above narrative indicates that, by offering professional services to advocate diffusion, local entrepreneurs can play an important role in complementing the role of the government. In a similar vein, another recent study on entrepreneur-run incubators (Liu, 2017b) found that local business and entrepreneurs can complement the role of the government in fostering local entrepreneurial activities within the current framework of China's national mass entrepreneurship and innovation policy.

To sum up, institutional entrepreneurs interact with other actors in the form of collaborative partnerships by establishing new institutional arrangements. Other actors can advocate diffusion by offering ancillary services or complementing the role of the government. Collectively, entrepreneurial public-private collaborative partnerships are conducive to fostering regional entrepreneurship. Thus, we posit the following:

P2: In the form of collaborative partnership, institutional entrepreneurs deploy the mechanism of establishing new institutional arrangements, whereas other actors advocate diffusion

Recent developments in regional entrepreneurship in China demonstrated that other cities were emulating the Wuxi 530 Plan to attract overseas talent. For example, the neighbouring city of Suzhou, which was not attracting returnee entrepreneurs at the beginning, quickly learned and emulated the talent-attracting policy initiated by Wuxi (Liu, Cao, \& Xing, 2013). From a comparative perspective, the path dependence and path creation of regional entrepreneurship policies may at first diverge due to initial conditions, but will converge over time due to the acceptance and diffusion of the 530 Plan.

The most recent development in the Chinese innovation and entrepreneurship landscape was a manifestation of the vibrant diffusion-advocating activities. In June 2015, the State Council 
officially announced an important guiding policy document, "Suggestions on Policy Implementation and Promotion of Mass Entrepreneurship and Innovation 《关于大力推进大众 创业万众创新若干政策措施的意见》.” During the Summer Davos Summit of September 2015, Chinese Prime Minister Mr. Li Keqiang reiterated the importance of China's mass entrepreneurship and innovation policy as the new growth driver for the Chinese economy. According to the Ministry of Science and Technology, China boasts over 2,300 MEMS, in addition to 2,500 business incubators and accelerators, 11 national-level indigenous innovation demonstration districts and 146 national high-tech districts. These institutional arrangements inspired the vibrant development of entrepreneurial activities in China, which included both returnees and local entrepreneurs (Liu, 2017b). The establishment by institutional entrepreneurs of more new institutional arrangements at the regional and national levels can convey a positive signal to other actors - especially returnee and local entrepreneurs - to advocate the diffusion of activities. Thus, we posit the following:

P3: The more institutional arrangements are newly established by institutional entrepreneur, the more diffusion-advocating activities are undertaken by other actors

To advance our analysis from a theoretical standpoint, we propose a conceptual framework of institutional entrepreneurship and collaborative partnership. As shown in Figure 2, institutional environments exert functional and political pressure on institutional entrepreneurs, as the Wuxi local government demonstrated in our analysis. When initial trigger events generate entrepreneurial opportunities, institutional entrepreneurs can take advantage of such opportunities by mobilizing resources. When Dr Shi visited Wuxi by presenting the entrepreneurial opportunity, the Wuxi local government responded to this trigger event by supporting Dr Shi as technology entrepreneur to found and grow the solar energy venture. Initial successes motivate institutional entrepreneurs to institutionalize pilot initiatives by establishing 
separate entities outside of the existing institutions to protect the initial institutional changes (P1a). As a policy initiative, the 530 Plan was launched by the Wuxi local government after observing the initial success of Suntech Power, so as to institutionalize the support offered to technology entrepreneur. Initial successes spread legitimacy for other actors to follow and support institutional changes (P1b). The initial success of Suntech Power served as a role model for both overseas and domestic entrepreneurs to follow. From a temporal perspective, institutional entrepreneurs deploy mechanisms suited to initially establish new institutional arrangements, whereas other actors subsequently advocate diffusion in the form of collaborative partnerships (P2). Wuxi local government first established the 530 Plan, and afterwards both entrepreneurs and local business people collaborate with the local government to bolster the new institutional initiative. When more institutional arrangements are established by both central and local governments, manifested as the mass innovation and entrepreneurship policy in China, more diffusion-advocating activities undertaken by multiple actors occur (P3).

\section{INSERT Figure 2 ABOUT HERE}

\section{Discussion}

\section{Theoretical contribution}

This paper makes three contributions to the growing body of research on entrepreneurial publicprivate collaborative partnerships by (1) identifying the conditions that enable local governments, as institutional entrepreneurs, to take entrepreneurial actions suited to initiate institutional changes; (2) articulating the mechanisms deployed by institutional entrepreneurs and private entrepreneurs from a temporal perspective in the process of institutional change fostering regional entrepreneurship; (3) demonstrating the role played by returnees and their 
interaction with institutional entrepreneurs in the form of public-private collaborative partnerships fostering institutional changes.

First, our research indicates that, in China, local governments are institutional entrepreneurs. Our findings not only lend support to previous research that used institutional theory and highlighted the important role played by the state in emerging economies (Jain \& Sharma, 2013), but also advance the institutional entrepreneurship literature by demonstrating that local governments act as institutional entrepreneurs. In doing so, we contribute to a nuanced understanding of the role of government by articulating the contextual characteristics of regional competition in China $(\mathrm{Xu}, 2011)$. We also articulate the conditions enabling local governments to act as institutional entrepreneurs by juxtaposing the public management and entrepreneurship perspectives. The decentralized political constellations and regional differences found in local conditions engender an intense competition among local governments in China. Thus, local governments need to possess both the motivation and ability to capture entrepreneurial opportunities by responding to external events and mobilizing resources. The enabling conditions we identified contribute to the institutional entrepreneurship literature by highlighting the contextual characteristics of emerging economies, the governments of which tend to possess critical public resources that affect entrepreneurial activities (Armanios et al., 2017); however, both internal pressure and external demand are needed to trigger the institutional changes that are conducive to the engagement of returnee and private entrepreneurs.

Second, the existing research has acknowledged the importance of the collaborative partnership approach in fostering public entrepreneurship (Klein et al., 2013) and local economic development (Quelin et al., 2017). At the core of this kind of collaborative partnership are the mechanisms of interaction between participating actors. Previous research demonstrated the importance of agency autonomy in fostering public participation (Neshkova, 2014). However, in contrast to advanced economies, governments in emerging ones still hold great authority and 
power in regard to resource allocation (Holzer \& Zhang, 2009). Thus, a more enhanced and contextualized understanding of the intertwined mechanisms is needed. Our study can significantly expand the understanding of entrepreneurial public-private collaborative partnerships by explaining the interactions between local governments and private entrepreneurs, which are essential for local governments proactively seeking new engines for local economic development (Bernier \& Hafsi, 2007). Our findings contribute to achieve a nuanced understanding of the mechanisms, deployed by local governments and other actors from a temporal perspective, which underpin the collaborative partnerships between these actors in fostering regional entrepreneurship. The first mechanism involves the institutional entrepreneur, or local government, meeting the imperative of establishing new institutional arrangements that enable it to pilot and test the entrepreneurial approach. From the perspective of entrepreneurial public-private collaborative partnerships, local governments must, as a first step, establish the necessary institutional arrangements capable of bringing about the institutional changes. Furthermore, they need to establish separate entities to protect the institutional initiative. The second mechanism is the advocation of diffusion, by which other actors offer ancillary services and complement the role of governments in supporting returnee entrepreneurial activities. Initial success plays a critical role in the institutional entrepreneurs' ability to establish the legitimacy of their support for pilot initiatives. Thus, our results highlight the dynamics and complexity of institutional change involving entrepreneurial public-private partnerships in fostering regional entrepreneurship.

Third, our research makes a further contribution to the nascent literature on returnee entrepreneurship and regional development (Wang \& Liu, 2016; Wang, 2015). Our conceptual model for analysing entrepreneurial public-private collaborative partnerships reflects the interactive participation and engagement of multiple actors, especially the important role played by returnee entrepreneurs. The existing research on returnee entrepreneurship failed to uncover 
the interaction between returnees and local governments with a strong focus on individual behaviours or company-level performance consequences. Our findings support the use of such a paced approach to promote regional entrepreneurship, based on institutional initiatives led by local governments to grant its legitimacy, followed by diffusion activities deployed by other actors at the regional level. In the process of institutional change, returnees can play roles that go beyond those of knowledge brokers (Wang, 2015) or knowledge carriers for spillover effect (Filatotchev et al., 2011). Returnees can influence institutional change processes; in particular, any initial successes of returnees are attributed to motivating institutional entrepreneurs to initiate new institutional arrangements. Our findings also emphasize the joint influences exerted by governments on one hand, and regional circumstances — such as returnee entrepreneurs — on the other, in shaping the response of the government to the need for fostering regional entrepreneurship.

\section{Policy and managerial implications}

This study has several implications for policymakers and entrepreneurs. Governments should recognize and pay close attention to external actors and to their roles in regional entrepreneurship. The unprecedented pace of economic development in emerging economies confronts policymakers and business leaders with an economic environment that, much of the time, is globalized, interconnected, and turbulent. Entrepreneurial public-private collaborative partnerships can strongly affect the development of regional entrepreneurship. When a region in an emerging economy chooses to foster regional entrepreneurship, overseas entrepreneurs can actively shape this process by contributing their knowledge and, in the process, can benefit from such an institutional transformation. It may be more profitable for overseas entrepreneurs to deal with local governments, provided that they are aware of regional policies and that the governments are willing to collaborate with them. Such private-public collaborative 
partnerships have important implications for regional development and value creation (Quelin et al., 2017).

As for policy implications, emerging economies tend to resort to entrepreneurship to drive local economic development. For instance, Start-Up Chile, a government-backed ecosystem accelerator, provides government funds to support about 1,000 Chilean ventures (GonzalezUribe \& Leatherbee, 2015). Similar to Start-Up Chile, many emerging economies consider using business incubators to fill the institutional voids and encourage entrepreneurship (Dutt et al., 2016). However, our research indicates that attempts by governments to lure returnees can be a key component of the overall strategies aimed at promoting regional entrepreneurship in China (Wang \& Liu, 2016). The focus on attracting talent, especially returnee talent, is unique to the Chinese governmental approach to fostering regional entrepreneurship. We argue that other emerging economies may systematically design and implement policy initiatives to attract entrepreneurial talent and integrate them into the existing business incubators and accelerators. Our study may shed some revealing lights on policy making and implementation, especially with regard to refining policy initiatives to boost regional entrepreneurship and cultivate an atmosphere conducive to attracting returnee talent.

\section{Future research directions}

There are several fruitful research directions that can build on our initial attempt to address entrepreneurial public-private collaborative partnerships fostering regional entrepreneurship in emerging economies. First, future research can adopt a comparative perspective involving emerging economies and advanced ones. Prior research described the distinctive regional governance characteristics of China and the U.S. (Ye, 2009). A comparative approach could examine the variations across regions; as such, it would complement our longitudinal approach 
by investigating an extreme single case. Second, our research focusses mainly on the interaction between local governments and overseas entrepreneurs. A multitude of actors are involved in the interactions required to foster regional entrepreneurship. For example, the Triple Helix framework suggests that the university-industry-government interaction enables the development of a knowledge-based society and innovation, and contributes to regional development (Etzkowitz, 2008). Future work incorporating other actors, especially universities, can provide additional insights regarding entrepreneurial public-private collaborative partnerships both in general and in the specific context of regional entrepreneurship. Third, by examining the role played by local governments in fostering regional entrepreneurship, we extend the previous work on public-private collaborative partnerships (Liu et al., 2017). We identified two mechanisms of entrepreneurial public-private collaborative partnerships from a temporal perspective; future research could assess the generalizability of our results by means of quantitative studies across regions and/or countries.

\section{Conclusion}

This article identified the mechanisms underpinning public-private collaborative partnerships fostering entrepreneurship in emerging economies. In particular, it investigated how local governments deal with other actors - including returnee entrepreneurs, local entrepreneurs, and businesses - influencing institutional change and regional entrepreneurship from a temporal perspective in China. We identified the enabling conditions that can be set up by local governments as institutional entrepreneurs. Our study suggests that understanding the role played by governments and their relationships with other actors in a nuanced manner is important for advancing research on such collaborative partnerships. We hope that our study will inspire scholars to follow this line of inquiry into the role played by local governments in fostering regional entrepreneurship. In particular, our exploratory study offers an attempt to 
elucidate the complex interplay between local governments and other actors, and serves as a departure point for further theoretical refinement and empirical validation. 


\section{References}

Armanios, D. E., Eesley, C. E., Li, J., \& Eisenhardt, K. M. 2017. How entrepreneurs leverage institutional intermediaries in emerging economies to acquire public resources. Strategic Management Journal, 38(7): 1373-1390.

Ashworth, R., Ferlie, E., Hammerschmid, G., Moon, M. J., \& Reay, T. 2013. Theorizing contemporary public management: international and comparative perspectives. British Journal of Management, 24(S1): S1-S17.

Battilana, J., \& Casciaro, T. 2012. Change agents, networks, and institutions: A contingency theory of organizational change. Academy of Management Journal, 55(2): 381-398.

Battilana, J., Leca, B., \& Boxenbaum, E. 2009. How Actors Change Institutions: Towards a Theory of Institutional Entrepreneurship. Academy of Management Annals, 3: 65-107.

Bernier, L., \& Hafsi, T. 2007. The changing nature of public entrepreneurship. Public Administration Review, 67(3): 488-503.

Bjørnskov, C., \& Foss, N. J. 2016. Institutions, Entrepreneurship, and Economic Growth: What Do We Know and What Do We Still Need to Know? The Academy of Management Perspectives, 30(3): 292-315.

Bruton, G. D., Ahlstrom, D., \& Obloj, K. 2008. Entrepreneurship in emerging economies: Where are we today and where should the research go in the future. Entrepreneurship Theory and Practice, 32(1): 1-14.

Bruton, G. D., Filatotchev, I., Si, S., \& Wright, M. 2013. Entrepreneurship and strategy in emerging economies. Strategic Entrepreneurship Journal, 7(3): 169-180.

Bruton, G. D., Ketchen, D. J., \& Ireland, R. D. 2013. Entrepreneurship as a solution to poverty. Journal of Business Venturing, 28(6): 683-689.

Child, J., Lu, Y., \& Tsai, T. 2007. Institutional entrepreneurship in building an environmental protection system for the People's Republic of China. Organization Studies, 28(7): 10131034.

Dacin, M. T., Goodstein, J., \& Scott, W. R. 2002. Institutional theory and institutional change: Introduction to the special research forum. Academy of Management Journal, 45(1): 45-56.

David, R. J., Sine, W. D., \& Haveman, H. A. 2013. Seizing Opportunity in Emerging Fields: How Institutional Entrepreneurs Legitimated the Professional Form of Management Consulting. Organization Science, 24(2): 356-377.

Dean, T. J., \& McMullen, J. S. 2007. Toward a theory of sustainable entrepreneurship: Reducing environmental degradation through entrepreneurial action. Journal of business venturing, 22(1): 50-76.

Dutt, N., Hawn, O., Vidal, E., Chatterji, A., McGahan, A., \& Mitchell, W. 2016. How open system intermediaries address institutional failures: The case of business incubators in emergingmarket countries. Academy of Management Journal, 59(3): 818-840.

Edmondson, A. C., \& McManus, S. E. 2007. Methodological fit in management field research. Academy of management review, 32(4): 1246-1264.

Eesley, C. 2016. Institutional barriers to growth: Entrepreneurship, human capital and institutional change. Organization Science, 27(5): 1290-1306.

Etzkowitz, H. 2008. The Triple Helix: University-Industry-Government Innovation in Action London: Routledge.

Felin, T., Foss, N. J., \& Ployhart, R. E. 2015. The microfoundations movement in strategy and organization theory. The Academy of Management Annals, 9(1): 575-632.

Filatotchev, I., Liu, X., Lu, J., \& Wright, M. 2011. Knowledge spillovers through human mobility across national borders: Evidence from Zhongguancun Science Park in China. Research Policy, 40(3): 453-462.

Gehman, J., Lounsbury, M., \& Greenwood, R. 2016. How Institutions Matter: From the Micro Foundations of Institutional Impacts to the Macro Consequences of Institutional Arrangements. In J. Gehman, M. Lounsbury, \& R. Greenwood (Eds.), How Institutions Matter!, Volume 48A ed.: 1-34. Bingley: Emerald Group Publishing Limited.

George, G. 2014. Rethinking management scholarship. Academy of Management Journal, 57(1): 1-6. 
Gioia, D. A., Corley, K. G., \& Hamilton, A. L. 2013. Seeking qualitative rigor in inductive research notes on the Gioia methodology. Organizational Research Methods, 16(1): 15-31.

Gonzalez-Uribe, J., \& Leatherbee, M. 2015. Business Accelerators: Evidence from Start-Up Chile: SSRN eLibrary.

Greenwood, R., Hinings, C., \& Whetten, D. 2014. Rethinking institutions and organizations. Journal of Management Studies, 51(7): 1206-1220.

Greenwood, R., \& Hinings, C. R. 1993. Understanding strategic change: The contribution of archetypes. Academy of Management Journal, 36(5): 1052-1081.

Greenwood, R., \& Suddaby, R. 2006. Institutional entrepreneurship in mature fields: The big five accounting firms. Academy of Management Journal, 49(1): 27-48.

Hartley, J., Sørensen, E., \& Torfing, J. 2013. Collaborative innovation: A viable alternative to market competition and organizational entrepreneurship. Public Administration Review, 73(6): 821830.

Hinings, C. R., \& Greenwood, R. 1989. The dynamics of strategic change: B. Blackwell.

Holzer, M., \& Zhang, M. 2009. Introduction to the special issue on comparative Chinese/American public administration. Public Administration Review, 69(s1): S5-S12.

Huggins, R., \& Williams, N. 2011. Entrepreneurship and regional competitiveness: The role and progression of policy. Entrepreneurship \& Regional Development, 23(9-10): 907-932.

Isenberg, D. J. 2010. How to start an entrepreneurial revolution. Harvard Business Review, 88(6): 4050.

Jain, S., \& Sharma, D. 2013. Institutional logic migration and industry evolution in emerging economies: the case of telephony in India. Strategic Entrepreneurship Journal, 7(3): 252271.

Jennings, P. D., Greenwood, R., Lounsbury, M. D., \& Suddaby, R. 2013. Institutions, entrepreneurs, and communities: A special issue on entrepreneurship. Journal of Business Venturing, 28(1): $1-9$.

Johns, G. 2017. Incorporating Context in Organizational Research: Reflections on the 2016 AMR Decade Award. Academy of Management Review: Published online before print February 24, 2017.

Kenney, M., Breznitz, D., \& Murphree, M. 2013. Coming back home after the sun rises: Returnee entrepreneurs and growth of high tech industries. Research Policy, 42(2): 391-407.

Klein, P. G., Mahoney, J. T., McGahan, A. M., \& Pitelis, C. N. 2013. Capabilities and strategic entrepreneurship in public organizations. Strategic Entrepreneurship Journal, 7(1): 70-91.

Li, H., Zhang, Y., Li, Y., Zhou, L. A., \& Zhang, W. 2012. Returnees Versus Locals: Who Perform Better in China's Technology Entrepreneurship? Strategic Entrepreneurship Journal, 6(3): 257-272.

Liou, K. T. 2009. Local economic development in China and the United States: Strategies and issues. Public Administration Review, 69(s1): S29-S37.

Lippmann, S., \& Aldrich, H. E. 2016. A rolling stone gathers momentum: Generational units, collective memory, and entrepreneurship. Academy of Management Review, 41(4): 658-675.

Liu, X., Lu, J., Filatotchev, I., Buck, T., \& Wright, M. 2010. Returnee entrepreneurs, knowledge spillovers and innovation in high-tech firms in emerging economies. Journal of International Business Studies, 41(7): 1183-1197.

Liu, Y. 2017a. Born global firms' growth and collaborative entry mode: the role of transnational entrepreneurs. International Marketing Review, 34(1): 46-67.

Liu, Y. 2017b. Transnational entrepreneurship and entrepreneurial ecosystem: The role of organizational ambidexterity and entrepreneurial intensity. Small Business Economics, Conditional Acceptance.

Liu, Y., \& Almor, T. 2016. How culture influences the way entrepreneurs deal with uncertainty in inter-organizational relationships: The case of returnee versus local entrepreneurs in China. International Business Review, 25(1): 4-14.

Liu, Y., Cao, X., \& Xing, Y. 2013. A Tale of Two Cities in Regional Entrepreneurial Policymaking: A Comparative Study of Suzhou and Wuxi from a Path Dependence Perspective. In J. Sydow, \& G. Schreyogg (Eds.), Self-reinforcing Processes in and among Organizations: 55-80: Palgrave Macmillan. 
Liu, Y., Sarala, R. M., Xing, Y., \& Cooper, C. L. 2017. Human side of collaborative partnerships: A micro-foundational perspective. Group \& Organization Management, 24(2): 151-162.

Liu, Y., Xing, Y., \& Starik, M. 2012. Storytelling as Research Method: A West-Meets-East Perspective. In C. L. Wang, D. J. Ketchen, \& D. D. Bergh (Eds.), Research Methodology in Strategy and Management, Vol. 8: 143-171: Emerald Group Publishing Limited.

Locke, K. 2011. Field research practice in management and organization studies: reclaiming its tradition of discovery. The Academy of Management Annals, 5(1): 613-652.

Lounsbury, M., \& Beckman, C. M. 2015. Celebrating organization theory. Journal of Management Studies, 52(2): 288-308.

Lounsbury, M., \& Crumley, E. T. 2007. New practice creation: An institutional perspective on innovation. Organization Studies, 28(7): 993-1012.

Mahoney, J. T., McGahan, A. M., \& Pitelis, C. N. 2009. Perspective-The interdependence of private and public interests. Organization Science, 20(6): 1034-1052.

Mair, J., \& Marti, I. 2009. Entrepreneurship in and around institutional voids: A case study from Bangladesh. Journal of Business Venturing, 24(5): 419-435.

Minniti, M. 2008. The role of government policy on entrepreneurial activity: productive, unproductive, or destructive? Entrepreneurship Theory and Practice, 32(5): 779-790.

Nasra, R., \& Dacin, M. T. 2010. Institutional Arrangements and International Entrepreneurship: The State as Institutional Entrepreneur. Entrepreneurship Theory and Practice, 34(3): 583-609.

Nee, V., \& Opper, S. 2012. Capitalism from below: markets and institutional change in China. Cambridge, MA: Harvard University Press.

Neshkova, M. I. 2014. Does Agency Autonomy Foster Public Participation? Public Administration Review, 74(1): 64-74.

Oliver, C. 1991. Strategic Responses to Institutional Processes. Academy of Management Review, 16(1): 145-179.

Quelin, B. V., Kivleniece, I., \& Lazzarini, S. 2017. Public-Private Collaboration, Hybridity and Social Value: Towards New Theoretical Perspectives. Journal of Management Studies, 54(6): 764792.

Reay, T., Golden-Biddle, K., \& Germann, K. 2006. Legitimizing a new role: Small wins and microprocesses of change. Academy of Management Journal, 49(5): 977-998.

Ribeiro-Soriano, D., \& Galindo-Martín, M.-Á. 2012. Government policies to support entrepreneurship. Entrepreneurship \& Regional Development, 24(9-10): 861-864.

Rosile, G. A., Boje, D. M., Carlon, D. M., Downs, A., \& Saylors, R. 2013. Storytelling Diamond An Antenarrative Integration of the Six Facets of Storytelling in Organization Research Design. Organizational Research Methods, 16(4): 557-580.

Smallbone, D., \& Welter, F. 2012. Entrepreneurship and institutional change in transition economies: The Commonwealth of Independent States, Central and Eastern Europe and China compared. Entrepreneurship \& Regional Development, 24(3-4): 215-233.

Spencer, J. W., Murtha, T. P., \& Lenway, S. A. 2005. How governments matter to new industry creation. Academy of Management Review, 30(2): 321-337.

Thornton, P. H., \& Ocasio, W. 1999. Institutional logics and the historical contingency of power in organizations: Executive succession in the higher education publishing industry, 1958-1990. American Journal of Sociology, 105(3): 801-843.

Vaara, E., \& Monin, P. 2010. A Recursive Perspective on Discursive Legitimation and Organizational Action in Mergers and Acquisitions. Organization Science, 21(1): 3-22.

Wang, D. 2015. Activating Cross-border Brokerage Interorganizational Knowledge Transfer through Skilled Return Migration. Administrative Science Quarterly, 60(1): 133-176.

Wang, H., \& Liu, Y. 2016. Entrepreneurship and Talent Management from a Global Perspective: Global Returnees. Cheltenham: Edward Elgar.

White, S., Gao, J., \& Zhang, W. 2005. Financing New Ventures in China: System Antecedents and Institutionalization. Research Policy, 34(6): 894-913.

Wijen, F., \& Ansari, S. 2007. Overcoming inaction through collective institutional entrepreneurship: Insights from regime theory. Organization Studies, 28(7): 1079.

Wood, G., \& Wright, M. 2015. Corporations and New Statism: Trends and Research Priorities. The Academy of Management Perspectives, 29(2): 271-286. 
Wright, A. L., \& Zammuto, R. F. 2013. Creating opportunities for institutional entrepreneurship: The Colonel and the Cup in English County Cricket. Journal of Business Venturing, 28(1): 5168.

Xu, C. 2011. The fundamental institutions of China's reforms and development. Journal of Economic Literature: $1076-1151$.

Xu, D., \& Meyer, K. E. 2013. Linking theory and context:'Strategy research in emerging economies' after Wright et al.(2005). Journal of Management Studies, 50(7): 1322-1346.

Ye, L. 2009. Regional government and governance in China and the United States. Public Administration Review, 69(s1): S116-S121.

Zahra, S. A., \& Wright, M. 2011. Entrepreneurship's next act. The Academy of Management Perspectives, 25(4): 67-83.

Zahra, S. A., \& Wright, M. 2016. Understanding the Social Role of Entrepreneurship. Journal of Management Studies, 4(53): 610-629.

Zietsma, C., Groenewegen, P., Logue, D. M., \& Hinings, C. R. B. 2017. Field or fields? Building the scaffolding for cumulation of research on institutional fields. Academy of Management Annals, 11(1): 391-450.

Zilber, T. B. 2006. The work of the symbolic in institutional processes: Translations of rational myths in Israeli High Tech. Academy of Management Journal, 49(2): 281-303. 
Table 1. Primary interviewees

\begin{tabular}{|c|c|c|}
\hline Informants & $\begin{array}{l}\text { Number of } \\
\text { interviews }\end{array}$ & Roles and positions \\
\hline \multicolumn{3}{|l|}{ Local government officials } \\
\hline High-tech park & 6 & Director, deputy director, managers from \\
\hline \multirow[t]{2}{*}{ Regional gov. officials } & 7 & $\begin{array}{l}\text { Local Labour Resource Dept, Local Economic } \\
\text { Development Dept, } 530 \text { Service Office, and }\end{array}$ \\
\hline & & High-tech parks \\
\hline \multicolumn{3}{|l|}{$\underline{\text { WXOCICC association }}$} \\
\hline WXOCICC Chairman & 1 & Chairman, executive secretary, project \\
\hline Staff members & 3 & manager, network manager \\
\hline \multicolumn{3}{|l|}{$\underline{\text { Private entrepreneurs }}$} \\
\hline Returnee entrepreneurs & 9 & $\begin{array}{l}\text { Returnees: solar industry, biotech, software, } \\
\text { e-commerce, ICT, IT outsourcing }\end{array}$ \\
\hline Local entrepreneurs, business & 6 & $\begin{array}{l}\text { Locals: law, accountant, business consulting, } \\
\text { market research, recruiting agent, Venture }\end{array}$ \\
\hline & & Capital companies \\
\hline
\end{tabular}


Table 2. Wuxi Policy documents analysed

\begin{tabular}{|c|c|c|}
\hline Policy Document & $\begin{array}{l}\text { Document Issue } \\
\text { Time }\end{array}$ & Key Aspects \\
\hline $\begin{array}{l}\text { "Decision on implementing } \\
\text { the ' } 530 \text { Plan' in } 2008 \text { " }\end{array}$ & $(2007.12)$ & $\begin{array}{l}\text { Aimed at attracting overseas expatriates to } \\
\text { start up businesses to take advantage of their } \\
\text { special technological know-how }\end{array}$ \\
\hline $\begin{array}{l}\text { "Plans for Propelling the } \\
\text { Commercialization of } \\
\text { Pioneering Returnee } \\
\text { Entrepreneurs Project" }\end{array}$ & $(2008.10)$ & $\begin{array}{l}\text { Industrialization and commercialization of } \\
\text { technologies of overseas expatriates }\end{array}$ \\
\hline $\begin{array}{l}\text { "Approval of Development } \\
\text { Planning of Wuxi as National } \\
\text { High-Tech Industries Base" }\end{array}$ & $(2008.11)$ & $\begin{array}{l}\text { Aimed at achieving reputation as a national } \\
\text { base }\end{array}$ \\
\hline $\begin{array}{l}\text { "Decision on setting up the } \\
\text { "530 Plan' Experts Consulting } \\
\text { Committee" }\end{array}$ & $(2009.7)$ & $\begin{array}{l}\text { Setting up a consulting committee to } \\
\text { facilitate } 530 \text { Plan investment decisions }\end{array}$ \\
\hline $\begin{array}{l}\text { "Action Plan to Achieve } \\
\text { Agriculture Modernization in } \\
\text { 2009-2012" }\end{array}$ & (2009.10) & $\begin{array}{l}\text { Aimed at developing a modern agricultural } \\
\text { industry in Wuxi }\end{array}$ \\
\hline $\begin{array}{l}\text { "Policies to Support the } \\
\text { Development of Cartoon \& } \\
\text { Game Industries" }\end{array}$ & $(2010.2)$ & $\begin{array}{l}\text { Aimed at developing a new industry for the } \\
\text { production of cartoon and games }\end{array}$ \\
\hline $\begin{array}{l}\text { "Planning to Introduce } \\
\text { Pioneering Bio-Agriculture } \\
\text { Professionals" }\end{array}$ & (2010.4) & $\begin{array}{l}\text { Aimed at attracting professionals in the bio- } \\
\text { agriculture field to support a planned } \\
\text { modern agricultural industry }\end{array}$ \\
\hline $\begin{array}{l}\text { "Policies to Quicken Modern } \\
\text { Service Industry } \\
\text { Development" }\end{array}$ & $(2010.11)$ & $\begin{array}{l}\text { Aimed at encouraging the development of a } \\
\text { modern service industry with favourable } \\
\text { policies }\end{array}$ \\
\hline $\begin{array}{l}\text { "General Planning and Action } \\
\text { Plan to Develop the National } \\
\text { Physical Network Innovation } \\
\text { Demonstration Zone in 2010- } \\
\text { 2015" }\end{array}$ & $(2010.8)$ & $\begin{array}{l}\text { Aimed at obtaining state support for the } \\
\text { approval and establishment of a National } \\
\text { Physical Network Innovation Demonstration } \\
\text { Zone in Wuxi }\end{array}$ \\
\hline $\begin{array}{l}\text { "Taihu Summit of "A } \\
\text { Thousand Talents"" }\end{array}$ & (2010.9) & $\begin{array}{l}\text { Aimed at establishing the reputation of } \\
\text { Wuxi as an attractive location for the } \\
\text { "Thousand Talents" programme, cultivating } \\
\text { and attracting strategic new industries, } \\
\text { bringing together entrepreneurs and venture } \\
\text { capitals }\end{array}$ \\
\hline
\end{tabular}


Table 3. Dimensions, Themes, Categories, and Data

TABLE 3 Dimensions, Themes, Categories, and Data

\section{Second-Order Themes and First-Order Categories}

\section{Representative Data}

Overarching dimension: The establishment of new institutional arrangements

1. Modifying

A. Local economic structure upgrading /

transformation pressure

B. Improvement of local socio-cultural atmosphere and demography

2. Separating from existing institutions

C. Local government respond to Suntech case

A1. "We started early in 2006 with 530 Plan, sort of earlybird in the national wide industry structure transformation process. The traditional industry structure is not sustainable. Wuxi found the way in attracting High-tech talent." (director of Wuxi 530 Entrepreneur Service Center)

A2. "When we carry 530 projects, we select those projects fit to [...] district. Such as new energy or design-related projects." (director at one Wuxi Economic Development Zone)

B1. "The arrival of talents brings an upgrade for the citizen composition. In the past, Wuxi is lack of culture. For example, there is only one university here." (director of 530 service department)

B2. "Wuxi's population increased many times since 80 s, most of them are floating labors working for the manufacturing industry. They are not well educated, hence are not aware of the resource utilization. The 530 firms people extensively improve the labor structure and social atmosphere." (deputy director of a High-tech Park)

C1. "Mr. Li gathered 6 million RMB from State-owned enterprise, such as Little Swan to invest in Suntech. It was an individual investment case." (deputy director of labor resource department in one Wuxi district)

C2. The local Wuxi government was determined to let Dr. Shi become rich through an NYSE IPO. Local government strongly supported technology entrepreneurs and wanted to create a role model for follow-up entrepreneurs. This statement sent a strong signal that the Wuxi government respects the achievements of high-tech entrepreneurs and is willing to protect their benefits." (chairman of WXOCICC) 
D. Pioneer overseas entrepreneurs negotiate for government support

E. 530 Plan legitimates government support

Overarching dimension: The advocation of diffusion

3. Offering ancillary services

F. Involvement of professional service firms to support 530 firms
D1. "Back in 2000, we were the first group of overseas entrepreneurs in Wuxi, and we created three national No.1, i.e. Suntech in solar energy, Memsic in semiconductor, and Huaxia Computer in software-outsourcing. We argue that talents should be awarded when they arrive, not until their success. Mr. Yang said every year about 5 talents, 5 years around 30 . The firms can receive seed capital up to 100 Wan RMB. That is the original name of 530." (chairman of WXOCICC)

D2. "WXOCICC was founded in 2003. The foundation dinner was just one table containing the pionner of overseas entreprenuers in Wuxi. We talked to the government and asked for some support for overseas entreprenuers when they arrive." (chairman of WXOCICC)

E1. "There was no 530 Plan in 2001. Suntech was a successful case, and Wuxi saw the benefits from overseas technology talent, hence installed the 530 Plan to attract overseas entrepreneurs with various benefits." (director at one Wuxi Economic Development Zone)

E2. "According to 530 Plan, A class firm can receive 100 Wan RMB seed capital, over 100 square meters office, and over 100 square meters appartment three years free of charge. In addition, there is government VC and government guarantee loans available for 530 firms." (park manager at one High-tech Park)

F1. "We build a platform to optimally allocate the society resources. As agreed, the professional service firms offer services free of charge at the early-stage of 530 firms. Such as finanical advisory does not receive payment. But in the future when the 530 firms grow rapidly, e.g. IPO, the financial advisory firm will be called upon. They know the firms since inception. And 530 firms trust them." (director at Wuxi 530 Entrepreneur Service Center)

F2. "Service firms may help 530 firms find potential customers. They may hence form an industry chain. In our district about ten firms have direct supplier-buyer relationships."

(deputy director of a High-tech Park) 
G. Service platform to mobilize various resource participation

4. Complementing the role of government

H. Local government outsource services to local business

I. Participation of private enterprises

joining force with 530 firms
G1. "Offering the industry salon hopes to coordinate the resources within in the industry. Some companies form vertical partnership via such salon, such as technical cooperation and purchasing. 530 firms can obtain helpful information, whereas different resources can participate in the growth of 530 firms." (director at Wuxi 530 Entrepreneur Service Center)

G2. "Chamber of commerce gathers 530 firms in [...] district. It is a non-government organization. The various activities offer 530 firms the opportunity to mingle with research institutes, industry experts and established companies." (director at Wuxi 530 Entrepreneur Service Center)

H1. "In late 2008 and early 2009 , to better serve 530 firms, two special institutions were established, one is Wuxi 530 Entrepreneur Service Center, and the other is 530 projects Promotion Center. Now we provide 6 platforms offering services ranging from financial capital, HR, legal issue, sales and marketing, entrepreneur coaching, to normal life. It is designed to assist 530 firms."

(director at Wuxi 530 Entrepreneur Service Center)

$\mathrm{H} 2$. "I feel that the local government now is very open. They actively outsource specialized tasks to professionals. I think that running a company is not the local government's strength. The local government trusts the professional service companies, including VCs. Looking from the perspective of the high-tech park operation, we helped carry out several functions on behalf of the local government." (local professional service company owner)

I1. "Private enterprises in traditional industry are also actively involved. Their industry might not be the sun-rise sector. They are willing to invest in 530 firms to diversify their business lines." (director at one Wuxi Economic Development Zone)

I2. "The 530 firms need to team up with local Chinese firms. The marriage of technology with marketing know-how may generate returns. Pure technology does not count." (chairman of WXOCICC) 
Table 4. Enabling conditions for local government as institutional entrepreneur

\begin{tabular}{lcc}
\hline Theoretical & Enabling & Relation to local \\
perspective & conditions & government
\end{tabular}

\begin{tabular}{|c|c|c|}
\hline $\begin{array}{l}\text { Public } \\
\text { management }\end{array}$ & $\begin{array}{l}\text { Functional and } \\
\text { political } \\
\text { pressures }\end{array}$ & $\begin{array}{l}\text { Faced by local } \\
\text { government }\end{array}$ \\
\hline
\end{tabular}
Wuxi is a peripheral region, not like Shanghai that receives
worldwide attention. Shanghai is the primary location chosen for
Fortune 500 company headquarters in China, and the priority of the Shanghai government is to attract Fortune 500 companies. Although the local Wuxi government has worked hard to attract foreign direct investment (FDI), Wuxi lags far behind Shanghai in luring Fortune 500 companies. (head of local economic development department)

Wuxi's local economy was supported mainly by the manufacturing and textile industries in the early 2000s. That industrial structure polluted the local environment and was unsustainable in the long run for purposes of regional economic growth. Therefore, the local government faces enormous pressure to upgrade its industrial structure. In 2011, Wuxi's key economic engine and contributor is a renewable industry, the solar panel sector. This local structural change in the industry is due to the entrepreneurial behaviour of the local Wuxi government, which supports solar panel companies. (Chief of Staff of Labour Resources in Wuxi)

Entrepreneurship Opportunity For local government

Armed with know-how and industry experience in solar panel technology, Dr. Shi wanted to found his own solar venture in China in the early 2000s. He visited several places in China before meeting Mr. Li, former Director of Foreign Economics and Trade in Wuxi. Dr. Shi asked mainly for financial support, as solar panel 
manufacturing is capital intensive. Dr. Shi was turned down by all other regions except Wuxi. Promoted strongly by Mr. Li, the solar panel industry has the potential to upgrade local industrial structure. Therefore, the Wuxi local government decided to invest in this entrepreneurial opportunity. (Chairman of WXOCICC)

Wuxi's government has a professional team that can seize an opportunity. For example, I had this "Little handy brain" business plan that contained mainly our R\&D and industrial development ideas. We went to many places: the Pearl River Delta, the Yangzi River Delta. Very few people could understand our ideas. We passed through Wuxi on our way. One industrial park head said to me: "We need this venture here." In retrospect, we now appreciate Wuxi's foresight. Still, we have a long way to go. We successfully grew this venture from two persons to 100, generating an income of over 10 million RMB now. (530 entrepreneur)

Entrepreneurship Mobilizing resources
Ability of local government
After performing due diligence on Dr. Shi in Australia, the local Wuxi government decided to make the investment. However, no template was available on how to invest. Mr. Li assembled six million USD from State Owned Enterprises (SOE), e.g., Little Swan, to invest in Suntech. It was not a formal investment but rather an informal one led by Mr. Li. (chairman of WXOCICC)

Wuxi's policy now is to attract talent. Attracting talent can bring technology, technology can be applied to develop the product, the product can be made into commercial and industrial goods, and eventually there will be a new industrial value chain. Resources need to be moved to invest in talent, and ultimately this action can generate benefits for the regional economy as a whole, all based on this policy of attracting talent. (530 entrepreneur) 
Figure 1. Data structure

\section{First-Order Categories}

A. Local economic structure upgrading/ transformation pressure

B. Improvement of local socio-cultural atmosphere and demography

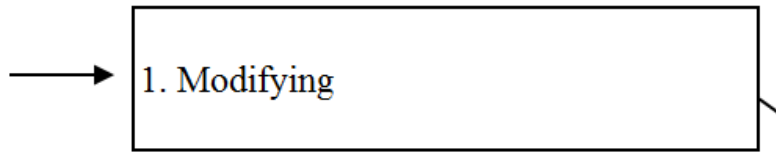

C. Local government reaction to Suntech case

D. Pioneer overseas entrepreneurs negotiate for government support

E. 530 Plan legitimates government support
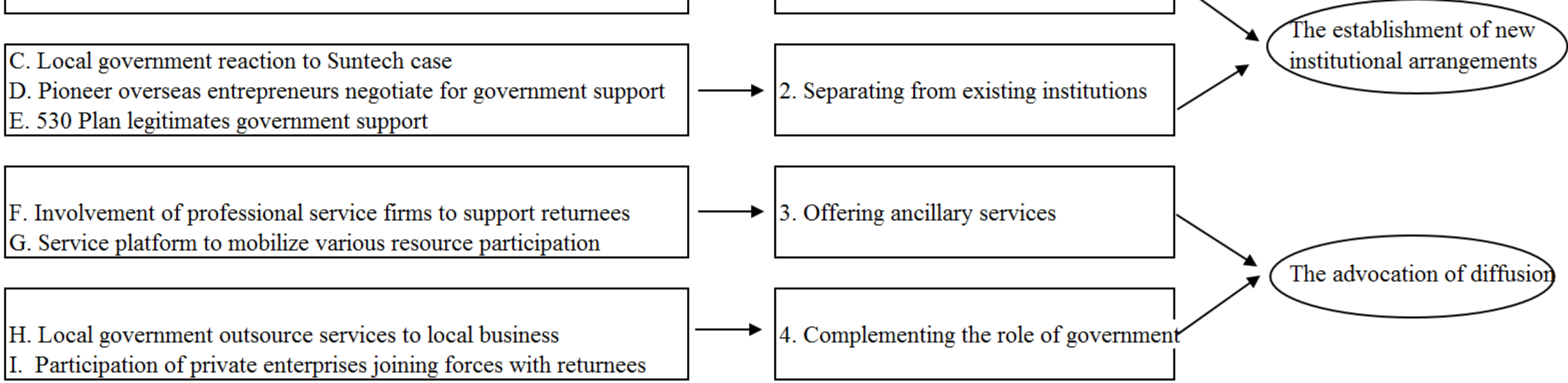

H. Local government outsource services to local business

I. Participation of private enterprises joining forces with returnees 
Figure 2. A conceptual framework of institutional entrepreneurship and collaborative partnership

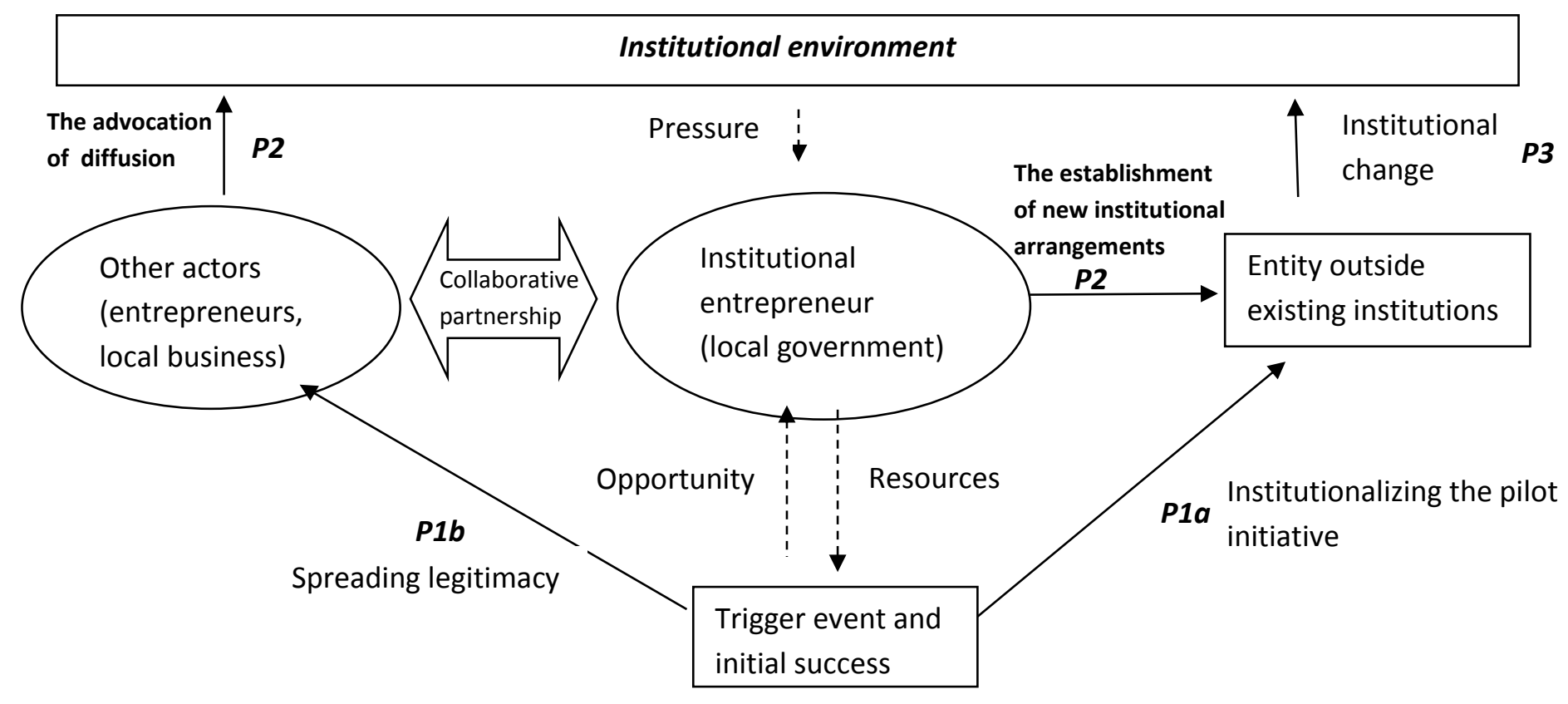

